\title{
防耐火試験における包括熱伝導率を用いたせっこうボードの遮熱性予測 STUDY ON PREDICTION METHOD FOR INSULATION OF GYPSUM BOARD USING “INCLUSIVE THERMAL CONDUCTIVITY” IN FIRE-RESISTANCE TEST
}

\author{
吉谷公江*, 清水貴史 ${ }^{* *}$, 吉田正友*** \\ Kimie YOSHITANI, Takafumi SHIMIZU and Masatomo YOSHIDA
}

\begin{abstract}
In this study, a prediction method of the unexposed surface temperature of a wall was proposed using "inclusive thermal conductivity" that takes into consideration heat and mass transfer in a material containing moisture. Inclusive thermal conductivity is estimated based on the results of temperature measurements from actual fire-resistance tests. The proposed method enables the estimation of thermal conductivities of materials that are difficult to assess using conventional technologies. Inclusive thermal conductivity is affected by the deterioration of evaporation and materials that is estimated from the fire-resistance test result. Unexposed surface temperature prediction of gypsum boards that have different thickness is numerical analysis by changing the number of the inclusive thermal conductivity. The inclusive thermal conductivity of gypsum board becomes larger as the temperature becomes higher. Unexposed surface temperature prediction is affected by the exposed surface temperature of the fire-resistance test, and that is a high accuracy as the difference of the material thickness is smaller. Exposed surface temperature obtained from the fire-resistance test result influenced the prediction of the unexposed surface temperature. The prediction accuracy of numerical analysis using the inclusive thermal conductivity was confirmed to be practically sufficient.
\end{abstract}

Keywords : Fire-resistance, Gypsum board, Unexposed surface temperature prediction, Insulation,

Finite-difference method, Inclusive thermal conductivity

防而扵性能，せっこうボード，裏面温度予測，遮熱性，差分法，包括熱伝導率

\section{1. はじめに}

外壁構造の防耐火性能は住宅に求められる性能の中でも特に重要 な要素であり、その性能を確認するために業務方法書 1)に基づいた 性能評価試験が行われる。防耐火試験では構成材料の損傷が激しい ため、外壁の仕様を繰り返し検討する場合、軽微な内容であっても その都度新たな実大の試験体を用意して加熱試験を行うこととなる。 その際には非常に多くの時間・労力を必要とする上、煙及び有機ガ スが発生し2)、試験員の健康を阻害する恐れもある。

その解決方法として、遮熱性 ${ }^{3) 4}$ の評価に数值計算手法による裏 面温度の予測が試みられており、これまでに松本 ${ }^{5)}$ 、吉田 ${ }^{6)}$ 、小幡 $ら^{7)}$ が一次元差分法を用いたコンクリートの温度予測手法を提案し ている。この中で、松本は熱と水分が同時に移動する点を考慮し、 含水や計算の適用範囲の影響による誤差についても検討しているが、 精度の向上には数值計算の複雑化や数多くの熱物性值のパラメータ が求められ、実用性が乏しいと考えられる。吉田は含水率の初期条 件として移動水分量を加味した台形分布により表して検討を行って
おり、小幡らは実測した熱物性值を用いて耐火被覆とコンクリート の間に仮想の空気層を設けることで温度履歴を再現している。また、 由田ら ${ }^{8)}$ は二次元差分法を用いて木造軸組外壁の温度予測を行って いる。近年では、水上 ${ }^{13)}$ が水分を含む壁体の $100^{\circ} \mathrm{C}$ における温度停 滞に着目し、その遮熱性について簡易予測式を提案している。また、 平山ら ${ }^{14)}$ は、乾式間仕切壁の裏面温度予測について検討を行ってい るが、クラックの影響を十分に反映できていない等の課題がある。 Eurocode $4^{9)}$ （以下、EC4 とする）では、水分蒸発の影響を比熱の 変化により表すことで、水分の移動にかかわる計算は不要としてい る。しかし、EC4 の熱物性值をそのまま使用すると、計算結果は実

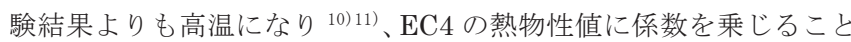
でコンクリート内部温度が精度良く予測できることが斎藤ら ${ }^{12)}$ に よって報告されている。

いずれの報告においても、熱物性值の温度依存性を考慮している ものの既知である必要がある。しかし、防耐火試験のような急激な 温度変化の下での熱物性值の挙動の把握は難しく、十分な検討はな
* 大和ハウス工業総合技術研究所

** 大和八ウス工業総合技術研究所 博士 (工学)

*** 大阪工業大学 特任教授・博士 (工学)
Daiwa House Industry Central Research Laboratory

Daiwa House Industry Central Research Laboratory, Dr.Eng.

Prof., Osaka Institute of Technology, Dr.Eng: 
されていない。さらに、水分の移動や蒸発、構成面材のクラックや 材料自体の燃焼といった試験体に生じる特異な条件を別途考慮しな ければならず、既存の測定法によって得られた熱物性值で十分な精 度の温度予測計算ができているとは言いがたい。

材料が片面から高温加熱を受ける場合、予測精度に大きな影響を 及ぼすクラックが材料の加熱側で発生し、材料内部へ広がっていく （Fig. 1）。そのため、加熱表面付近の損傷が最も激しく、内部、非 加熱側へ近づくほど材料の損傷度合は小さくなる。このように、加 熱側からの距離によって損傷度合が異なる場合、材料内の各部位に おいて熱伝導性が異なるうえ、温度上昇に伴って変化していくと考 えられる。加えて、材料内部の水分も非加熱側に移動し一様な分布 ではなくなるため、裏面温度予測の精度を求める際には、水分移動 の影響はもとより、クラックの影響についての精緻な測定や複雑な 数值計算が必要となる。

また、熱伝導率は熱物性值の中でも裏面温度予測に大きな影響を 及ぼすパラメータである ${ }^{16)}$ が、測定方法の違いによって大きく異な ることがわかっている ${ }^{17)}$ 。また、 $1000^{\circ} \mathrm{C}$ 付近まで測定可能な計測機 器は限定的であるため、数值計算においてそれらの利用の前提を避 ける必要がある。さらに、熱伝導率の測定結果 $\left.{ }^{18)}-20\right)$ でも示されてい るように、材料によって熱伝導率の温度依存性が異なる ${ }^{21)}$ ため、裏 面温度予測に対する影響の程度は検討を要する。したがって、裏面 温度予測に用いることのできる熱物性值の推定手法を確立できれば 非常に有用であるといえ、石原ら ${ }^{15)}$ が実験結果を基にした検討を行 ってはいるが、温度変化に伴うパラメータの変化が大きくないこと を条件にする等、この手法においてもやはりクラックの影響の取り 扱いが課題となっている。

一般的な住宅において、屋内側の仕上げ下地材に用いられるせっ こうボードは、耐火構造等の屋内加熱の際には高温に曝されてクラ ックや脱落が生じ、耐火性能に大きな影響を及ぼす。さらに、結晶 水を持つことから、自由水のみを持つ材料とは異なる温度履歴を示 すことが一般に知られている。また、水分の消失後はクラックが入 りやすく、温度予測を行う際には困難を生じる ${ }^{14)}$ 。

本研究では、このような性質を持つせっこうボードに対して、防 耐火試験の結果から推定する「水分を含む材料の温度依存性等を包 含した熱伝導率」（本研究では「包括熱伝導率 (Inclusive thermal conductivity)」と呼ぶ）を用い、厚さを薄くした場合の裏面温度の 予測手法を提案する。包括熱伝導率は、実際の防耐火試験結果に基 づいて推定するため、耐火炉内の加熱によって生じる含水の移動や 蒸発、高温下での変質や燃焼、微細なクラック等の影響も包含した ものといえる。したがって、包括熱伝導率は加熱側からの距離ごと に連続的に設定することで、水分の挙動を含めた材料の变質を実態 に即したものとして、遮熱性予測を行うことができる。

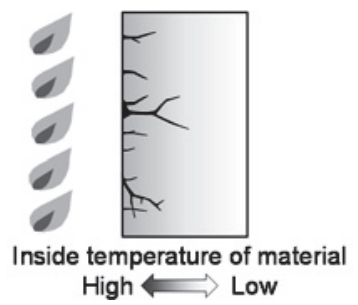

Fig. 1 Model of the material damage caused by one-sided heating

\section{2. せっこうボードの加熱実験}

\section{1 . 実験概要}

本実験では、Table 1 に示す 3 種類の厚さの JIS A 690122) の普通 せっこうボード（以降、せっこうボードとする）を用いて、幅 300 $\mathrm{mm} \times$ 高さ $300 \mathrm{~mm}$ の試験体とした。Fig. 2 に示すように、軽量鉄 骨製の試験体枠（幅 $760 \mathrm{~mm} \times$ 高さ $760 \mathrm{~mm}$ ）に各試験体を配置し、 試験体の加熱面が一辺 $200 \mathrm{~mm}$ となるようにした。試験体と試験体 枠との間、及び、試験体枠全体をセラミックファイバーにて被覆し、 試験体への熱の伝わりを防止した上で試験炉に鉛直に設置した (Photo 1)。試験体枠内における試験体の配置は、板厚の薄いもの を上部とし、燃え抜け等によって他の試験体に影響が出にくくなる よう配慮した。

Table 1 Specimens condition

\begin{tabular}{cccc}
\hline Specimen No. & E1 & E2 & E3 \\
\hline Thickness $(\mathrm{mm})$ & 9.5 & 12.5 & 15.0 \\
\hline Moisture content $(\%)^{22)}$ & 0.53 & 0.43 & 0.39 \\
\hline
\end{tabular}
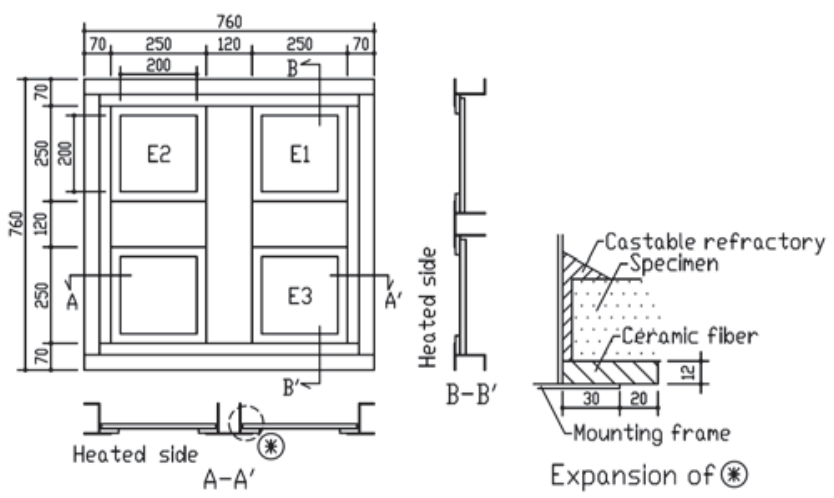

Fig. 2 Schematic (heated side) (Measurement unit: $\mathrm{mm}$ )

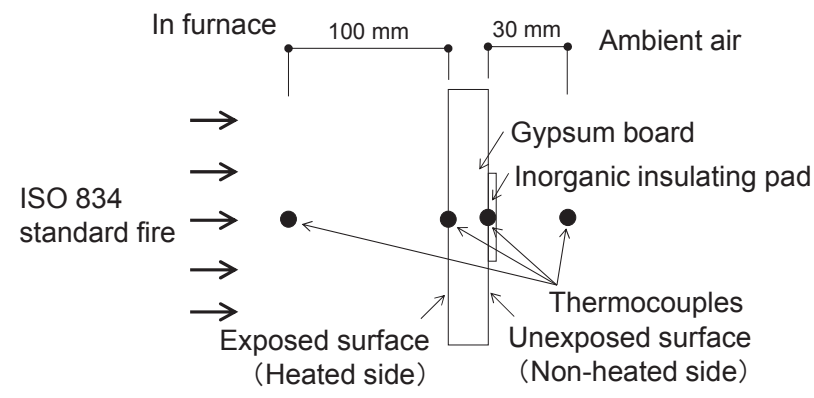

Fig. 3 Configuration of the thermocouples for temperature measurement

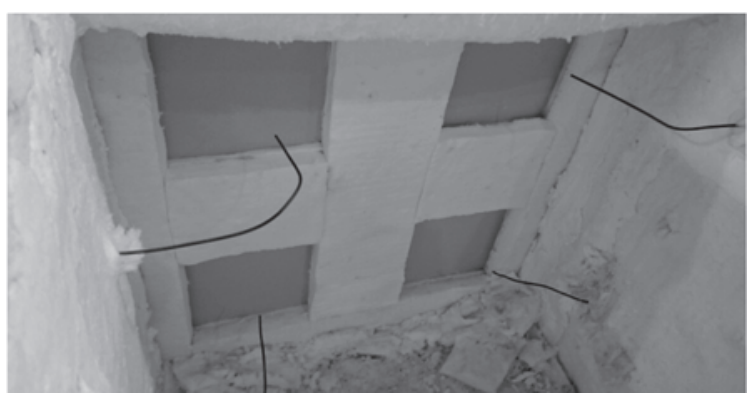

Photo 1 Set up condition of specimens (heated side) 
実験は、(一財) 日本建築総合試験所において、加熱面が一辺 670 $\mathrm{mm}$ となる小型試験炉を用い、式(1)によって表される ISO $834^{3)} に$ 準拠した標準加熱曲線にて加熱を行った ${ }^{1)}$ 。

$$
T_{f}=345 \log _{10}\left(8 t_{f}+1\right)+20
$$

ここで、 $T_{f}$ : 炉内温度 $\left({ }^{\circ} \mathrm{C}\right) 、 t_{f}$ : 時間 $(\mathrm{min})$ とする。

熱電対の設置位置を Fig. 3 に示寸。温度測定位置は、試験体表裏 面（K 型熱電対を用いて測定）のほかに、試験体の加熱面から 100 $\mathrm{mm}$ 離れた点にて炉内温度（K型シース熱電対）、及び、試験体の裏 面から $30 \mathrm{~mm}$ 離れた点にて裏面空気温度（K型熱電対）を測定し た。試験体の表面温度は加熱側表面から $1 \mathrm{~mm}$ 内部の温度とし、裏 面温度は銅板付熱電対を幅 $30 \mathrm{~mm} \times$ 高さ $30 \mathrm{~mm} \times$ 厚さ $2 \mathrm{~mm}$ の耐 火繊維パッドで覆い固定して測定した。

試験時間は全ての試験体が燃え抜けるまでとし、計測間隔は 10 秒 とした。試験体枠内の一部試験体が燃え抜けた場合は、その試験体 の裏面温度測定用熱電対を外した上でセラミックファイバーを用い て試験体の裏面を塞ぎ、その他の試験体について加熱試験を継続し た。

\section{2 . 実験結果}

実験結果を Fig. 4 亿示す。炉内温度の 10 分時点における落込み は試験炉の失火によるものである。その後、即座に再点火したため 実験結果にはほとんど影響なかった。また、各試験体の計測時間は 試験体が燃え抜けた時点までとしたため、E1 では 15 分、E2 では 24 分、E3 では 32 分までの測定となった。

表面温度は、13 分程度までは E1 よりも E2 の方が若干高くなっ ており、材料の厚さの違いだけではなく、炉内温度のばらつきや表 面温度測定用熱電対の設置深さのずれが表面温度に影響を及ぼした と考えらえる。裏面温度に、 $100^{\circ} \mathrm{C}$ 付近で水分の蒸発に起因する温度 停滞が見られる。詳細に見ると、いずれの試験体においても自由水 の蒸発による $100^{\circ} \mathrm{C}$ 未満での停滞後、結晶水の分解・蒸発によって $120^{\circ} \mathrm{C}$ 程度での停滞が生じており、せっこうボード特有の温度履歴 といえる。

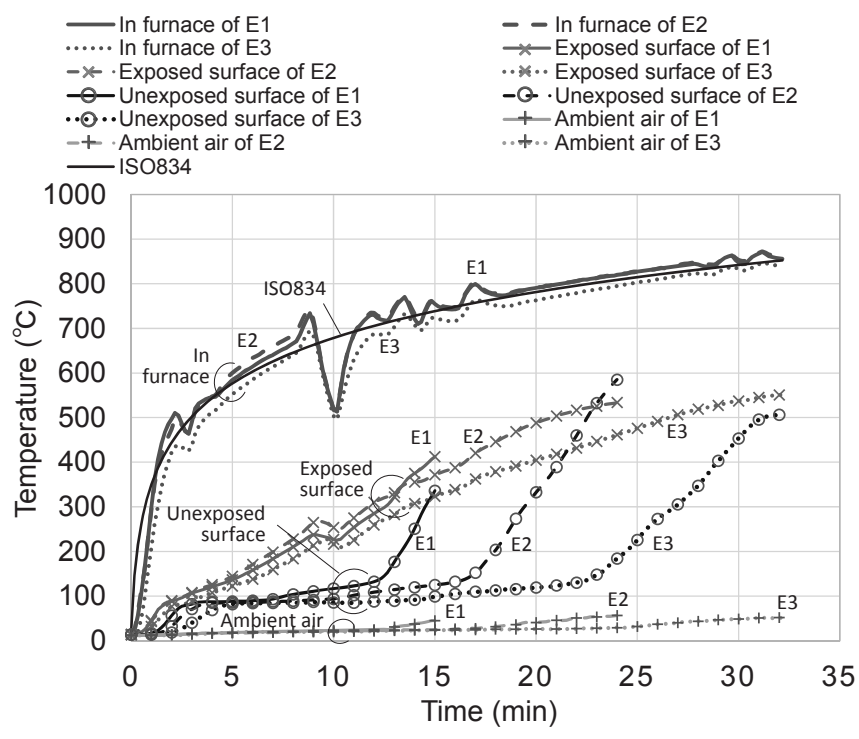

Fig. 4 Fire-resistance test result

\section{3. 包括熱伝導率の推定}

\section{1 . 数値計算手法}

防耐火試験では試験体に与える試験炉内の熱が標準加熱温度とし て規定されており、試験炉内における平面的な温度分布は一定の範 囲内に収まることを前提としている。したがって、壁の一般部にお いては片面からの一次元的な加熱とみなせるため、本研究では一次 元の解析モデル（Fig. 5） について前進差分法により検討すること とした。また、JIS ${ }^{23)}$ 24) における熱伝導率の測定も一次元的であると いえる。

1 次元非定常熱伝導方程式は、式(2)にて表される。

$$
\frac{\partial T}{\partial t}=\alpha_{\mathrm{j}}^{\mathrm{n}} \frac{\partial^{2} T}{\partial x^{2}} \quad(\mathrm{j}=1 \sim \mathrm{m})
$$

また、式(2)を有限差分法によって離散化すると、分割層の境界温度 は式(3)、せっこうボードの裏面温度は式(4)となる ${ }^{25)} 。$

$$
\begin{aligned}
\theta_{\mathrm{i}}^{\mathrm{n}+1}=F o_{\mathrm{i}+1}^{\mathrm{n}} \theta_{\mathrm{i}+1}^{\mathrm{n}}+\left(1-2 F o_{\mathrm{i}}^{\mathrm{n}}\right) \theta_{\mathrm{i}}^{\mathrm{n}}+ & F o_{\mathrm{i}-1}^{\mathrm{n}} \theta_{\mathrm{i}-1}^{\mathrm{n}} \\
& (\mathrm{i}=1 \sim \mathrm{m}-1)
\end{aligned}
$$

$$
\begin{aligned}
\theta_{\mathrm{m}}^{\mathrm{n}+1} & =2 F o_{\mathrm{m}-1}^{\mathrm{n}} \theta_{\mathrm{m}-1}^{\mathrm{n}} \\
& +\left(1-2 F o_{\mathrm{m}}^{\mathrm{n}}-2 h_{o} F o_{\mathrm{m}}^{\mathrm{n}} \frac{\Delta x}{\lambda_{\mathrm{m}}^{\mathrm{n}}}\right) \theta_{\mathrm{m}}^{\mathrm{n}} \\
& +2 h_{o} F o_{\mathrm{m}}^{\mathrm{n}} T_{o}^{\mathrm{n}} \frac{\Delta x}{\lambda_{\mathrm{m}}^{\mathrm{n}}}
\end{aligned}
$$

このとき、

$$
\begin{aligned}
& F o_{\mathrm{j}}^{\mathrm{n}}=\alpha_{\mathrm{j}}^{\mathrm{n}} \frac{\Delta t}{\Delta x^{2}}=\frac{\lambda_{\mathrm{j}}^{\mathrm{n}}}{\rho_{\mathrm{j}}^{\mathrm{n}} c_{\mathrm{j}}^{\mathrm{n}}} \cdot \frac{\Delta t}{\Delta x^{2}} \quad\left(0 \leqq F o_{\mathrm{j}}^{\mathrm{n}} \leqq 0.5\right) \\
& \Delta t=\frac{d t i m}{3600} \quad, \Delta x=\frac{d t h}{1000}
\end{aligned}
$$

ここで、 $T:$ 温度 $\left({ }^{\circ} \mathrm{C}\right) 、 t$ : 時間 $(\mathrm{h}) 、 x:$ 材料厚さ $(\mathrm{m}) 、 \alpha_{\mathrm{j}}^{\mathrm{n}}:$ 熱拡散率 $\left(\mathrm{m}^{2} / \mathrm{s}\right) 、 \mathrm{n}$ : ステップ数、 $\mathrm{m}$ : 分割層の数、 $\theta_{\mathrm{j}}{ }^{\mathrm{n}}:$ 第 $\mathrm{j}$ 層の非加熱側境 界温度 $\left({ }^{\circ} \mathrm{C}\right) 、 \lambda_{\mathrm{j}}^{\mathrm{n}}$ : 第 $\mathrm{j}$ 層の熱伝導率 $(\mathrm{W} /(\mathrm{mK})) 、 \rho_{\mathrm{j}}^{\mathrm{n}}$ : 密度 $\left(\mathrm{kg} / \mathrm{m}^{3}\right)$ 、 $c_{\mathrm{j}}{ }^{\mathrm{n}}$ : 比熱 $(\mathrm{kJ} /(\mathrm{kgK})) 、 F o_{\mathrm{j}}{ }^{\mathrm{n}}$ : フーリエ数、 $h_{o}$ : 非加熱側熱伝達率 $\left(\mathrm{W} /\left(\mathrm{m}^{2} \mathrm{~K}\right)\right) 、 T_{o}^{\mathrm{n}}$ : 裏面空気温度 $\left({ }^{\circ} \mathrm{C}\right) 、 \Delta t$ 及び $d t i m$ : 刻み時間 $(\Delta t:$ $\mathrm{h} 、$ dtim $: \mathrm{sec}) 、 \Delta x$ 及び $d t h:$ 分割層の厚さ $(\Delta x: \mathrm{m} 、 d t h: \mathrm{mm})$ で ある。

式(3)〜 (5) における熱伝導率 $\lambda_{\mathrm{j}}^{\mathrm{n}}$ の值を $0.001 \mathrm{~W} /(\mathrm{mK})$ ごと変化さ せて、計算結果と実験結果が一致したときの值を包括熱伝導率 $\lambda^{\mathrm{n}}{ }_{\text {inc.j }}$ とする(式(7))。

$$
\lambda_{\mathrm{j}}^{\mathrm{n}}=\lambda_{\text {inc.j }}^{\mathrm{n}}
$$

従来の数值計算手法では、材料内部の水分の移動を事前に検討し て水分量を三角や台形状に分布させることで、水分蒸発のある材料 の裏面温度の挙動の再現を試みている。しかし本来、水分は加熱と 共に移動して非加熱側に偏り、それと同時に蒸発するため、従来の 計算手法では水分蒸発の過程をとらえきれていないと考えられる。 また、試験体が片側加熱される場合、同一材料内においても水分量 や温度に分布が生じるため、材料内部の熱伝導率は場所毎に異なり、 規格に基づく測定值とは一致しないと考えられる。そのため、より 実態に則した裏面温度予測を行うためには、水分の挙動や温度依存 性を考慮した熱物性值が必要といえる。本研究で提案する包括熱伝 導率は、水分を含む材料の各分割層の温度依存性を包括したものて 
あり、防耐火試験時の状況を反映したものといえる。包括熱伝導率 は各分割層の熱伝導性を表すため、各分割層の中心温度 $\theta_{\mathrm{j}}{ }^{\mathrm{n}}$ (式 (8)) に依存するものとし、密度についても同様とする。

$$
\theta_{\mathrm{j}}^{\prime \mathrm{n}}=\frac{\theta_{\mathrm{j}-1}^{\mathrm{n}}+\theta_{\mathrm{j}}^{\mathrm{n}}}{2}
$$

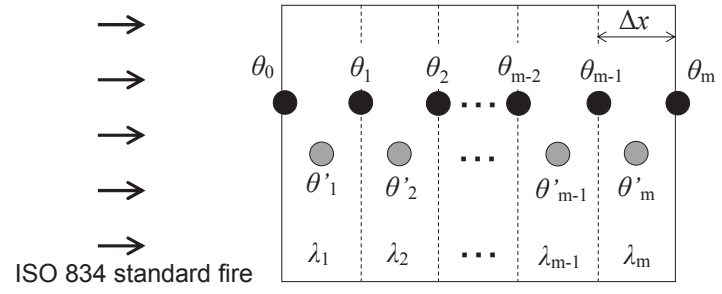

Fig. 5 Model of one-dimensional transient heat conduction equation

\section{2. 包括熱伝導率の推定}

上述の通り、防耐火試験に用いる材料は、同一材料内においても 加熱面からの距離によって加熱状況が異なるため、差分法による数 值計算を行う場合、材料を厚さ方向に分割し、分割層ごとに包括熱 伝導率を推定する。Fig. 6 に包括熱伝導率推定のフローチャートを 示す。

Fig. 7 に包括熱伝導率の推定対象 $\mathrm{E} 3$ 及び裏面温度の予測対象 N1 〜 N3 の概要を示寸。本章にて試験体厚さ $15 \mathrm{~mm}$ の $\mathrm{E} 3$ における包 括熱伝導率を推定し、4 章において分割層 1 層分薄い $\mathrm{N} 2$ 、及び、2 層分薄い $\mathrm{N} 1$ についての検討を行う。なお、加熱試験体 $\mathrm{E} 1$ 及び $\mathrm{E} 2$ と温度予測対象の $\mathrm{N} 1$ 及び $\mathrm{N} 2$ は、それぞれ $0.5 \mathrm{~mm}$ の厚さの違い があるが、表面温度の熱電対設置の誤差範囲であり、また、 $0.5 \mathrm{~mm}$ の違いによる温度差は非常に小さいと考え、無視できるものとする。

Table 2 に、E3 の包括熱伝導率の推定における初期条件を示す。 式(2)を用いてせっこうボードの熱伝導計算を行う場合、Fig. 8 に示 すように、実験より得られた表面温度を近似式（Fig. 9 及び式 (9)) にして加熱側の表面温度 $\theta_{0}$ に与え、裏面空気温度についても実験結 果を多項式近似した（Fig. 10 及び式(10))。このとき、表面温度を 直接与えることで、炉内の激しい対流によって特定の難しい加熱側 の熱伝達率の検討を省くことができる。

比熱 $c$ は一定とし、密度 $\rho$ は由田ら ${ }^{8)}$ が使用した值を用いた。そ のうち、水分蒸発後の值はせっこうボードとしての物性変化が終わ ると考えられる $400^{\circ} \mathrm{C}^{14)}$ での值とし、線形近似（Fig. 11 及び式(11) ) して用いた。また、分割層内の中心温度が $400^{\circ} \mathrm{C}$ 以上となる計算を 行う場合は、式(11)を外挿して線形近似した。

包括熱伝導率の推定においては、包括熱伝導率 $\lambda_{\text {inc. } 1} \sim \lambda_{\text {inc. } 5}$ を同時 にそれぞれ変化させて材料の内部及び裏面温度を計算し、Fig. 12 に 示すように材料内部の温度分布が加熱側から非加熱側に向かって段 階的に変化していることを確認した。計算結果と実験結果における 停滞時間、常温域及び $100^{\circ} \mathrm{C}$ 超の温度上昇のタイミング、収束温度 がほぼ一致した際の值を E3 の各分割層の包括熱伝導率とした。推 定した包括熱伝導率を Fig. 13 に示す。加熱される材料に含まれる 水分は加熱側から非加熱側へと移動するため ${ }^{5)}$ 、非加熱側に近づく につれて包括熱伝導率の変化量が大きくなり、最裏面層の包括熱伝 導率 $\lambda_{\text {inc. } 5}$ において最も顕著な変化が現れている。 $100^{\circ} \mathrm{C}$ 未満におい

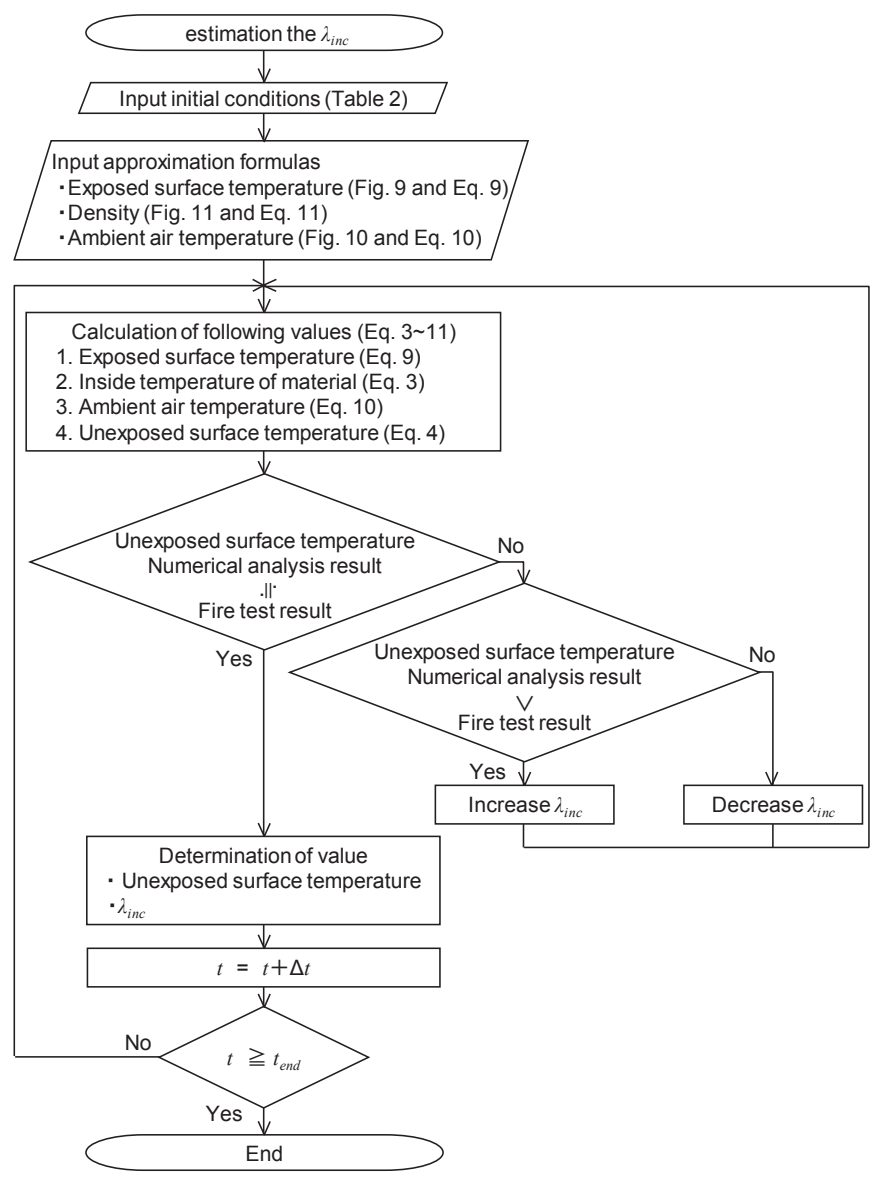

Fig. 6 Subroutine for estimating inclusive thermal conductivities shown as a flow chart

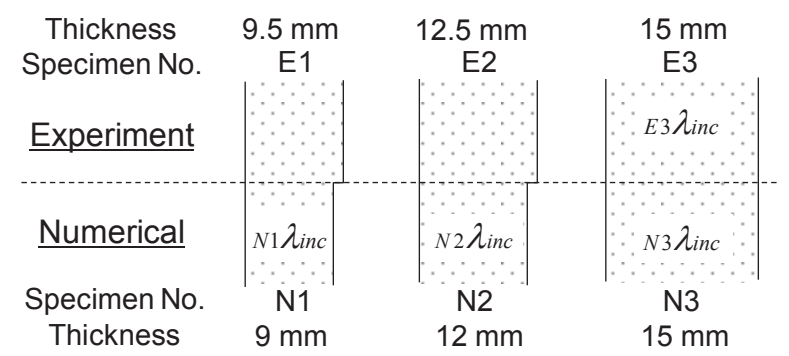

Fig. 7 Specimens and parameters for numerical analysis

Table 2 Initial condition for numerical analysis

\begin{tabular}{|c|c|c|c|}
\hline & N1 & $\mathrm{N} 2$ & $\begin{array}{l}\text { E3 } \\
\text { (N3) }\end{array}$ \\
\hline Thickness $(x)(\mathrm{m})$ & $9.0 \times 10^{-5}$ & -3 $12.0 \times 10^{-3}$ & $15.0 \times 10^{-3}$ \\
\hline Division number $(\mathrm{m})(-)$ & 3 & 4 & 5 \\
\hline Thickness of elements $(d t h)(\mathrm{mm})$ & & 3.0 & \\
\hline Time $\left(t_{f}\right)(\min )$ & 17.0 & 25.0 & 32.0 \\
\hline Time interval (dtim) (sec) & & 1.0 & $\begin{array}{c}3.0 \\
(1.0)\end{array}$ \\
\hline $\begin{array}{l}\text { Inclusive thermal conductivity } \\
\left(\lambda^{\mathrm{n}}{ }_{\text {inc. }}\right)(\mathrm{W} /(\mathrm{mK}))\end{array}$ & & $0.22^{8)}$ & \\
\hline Density $\left(\rho_{\mathrm{j}}^{\mathrm{n}}\right)\left(\mathrm{kg} / \mathrm{m}^{3}\right)$ & & $592.0^{8)}$ & \\
\hline Specific heat $\left(c_{\mathrm{j}}^{\mathrm{n}}\right)(\mathrm{kJ} /(\mathrm{kgK}))$ & & $1.0^{8)}$ & \\
\hline $\begin{array}{l}\text { Heat transfer coefficient of the } \\
\text { unexposed surface }\left(h_{o}\right)\left(\mathrm{W} /\left(\mathrm{m}^{2} \mathrm{~K}\right)\right)\end{array}$ & & $10.0^{13) 14)}$ & \\
\hline Material temperature $\left(\theta_{\mathrm{j}} \mathrm{n}\right)\left({ }^{\circ} \mathrm{C}\right)$ & & 13.7 & \\
\hline
\end{tabular}




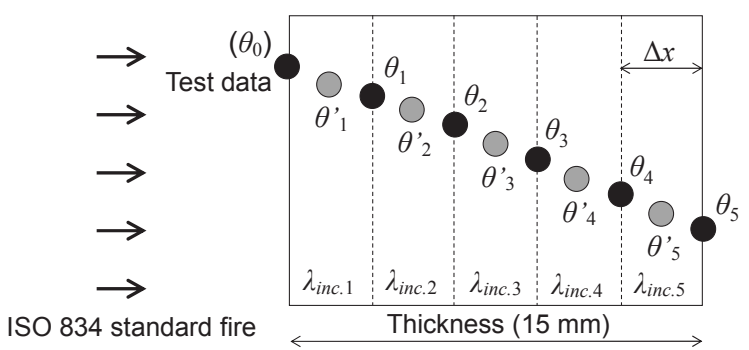

Fig. 8 numerical analysis (E3)

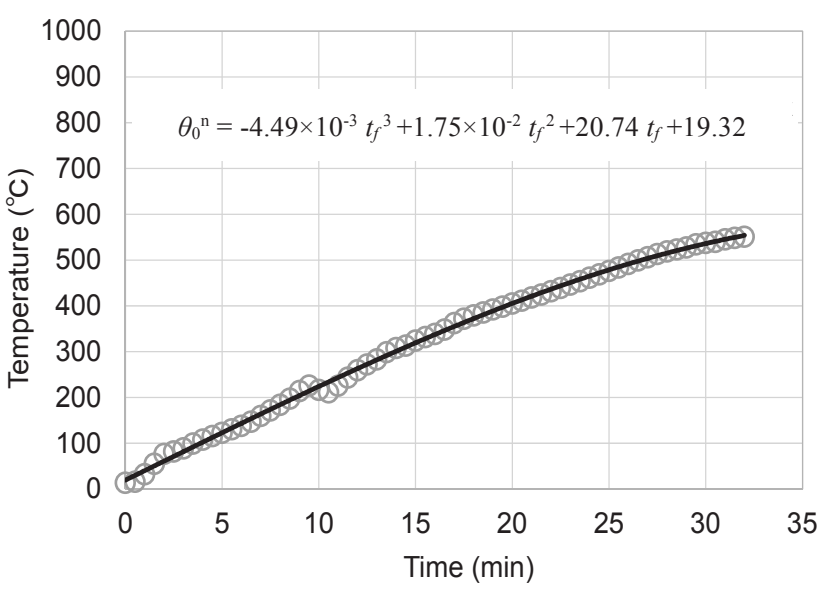

Fig. 9 Approximate curve in exposed surface temperature

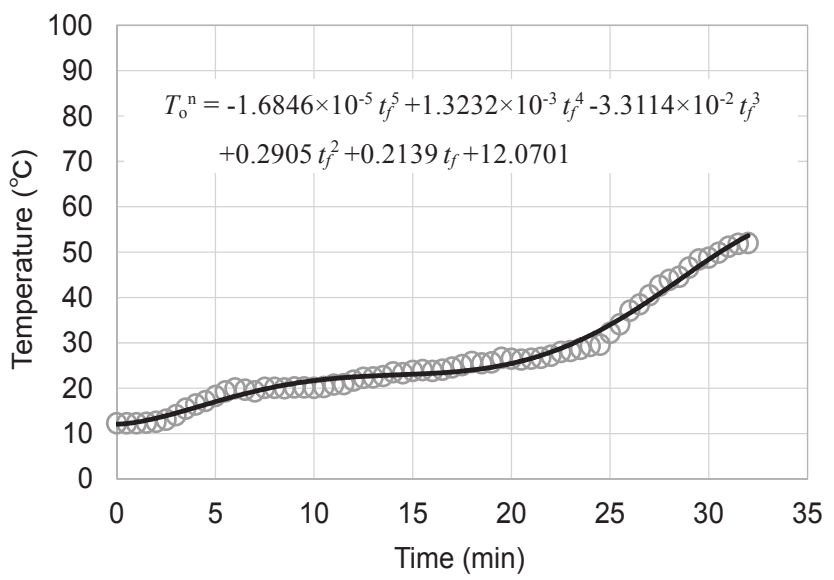

Fig. 10 Approximate curve in ambient air temperature

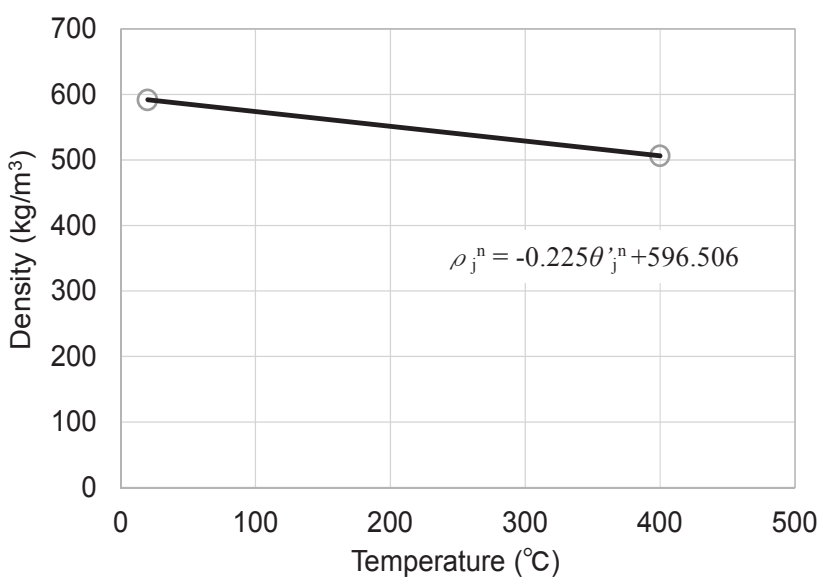

Fig. 11 Approximate line of density with temperature

$$
\begin{aligned}
\theta_{0}^{\mathrm{n}}= & -4.49 \times 10^{-3} t_{f}{ }^{3}+1.75 \times 10^{-2} t_{f}{ }^{2} \\
& +20.74 \times t_{f}+19.32 \\
T_{o}{ }^{\mathrm{n}}= & -1.6846 \times 10^{-5} t_{f}{ }^{5}+1.3232 \times 10^{-3} t_{f}{ }^{4} \\
& -3.3114 \times 10^{-2} t_{f}{ }^{3}+0.2905 t_{f}{ }^{2} \\
& +0.2139 t_{f}+12.0701 \\
\rho_{\mathrm{j}}^{\mathrm{n}}= & -0.225 \times \theta_{\mathrm{j}}^{\prime \mathrm{n}}+596.506
\end{aligned}
$$

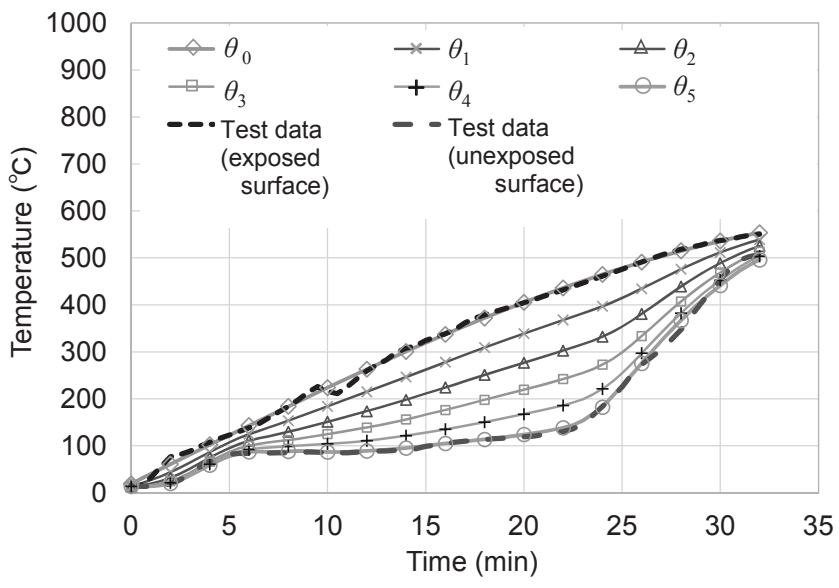

Fig. 12 Temperature distribution inside the gypsum board (E3)

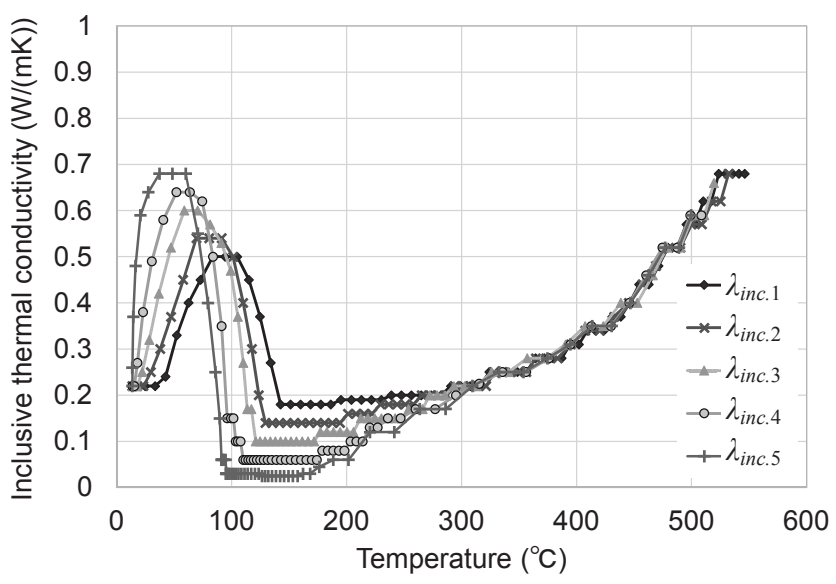

Fig. 13 Estimation result of the inclusive thermal conductivities (E3)

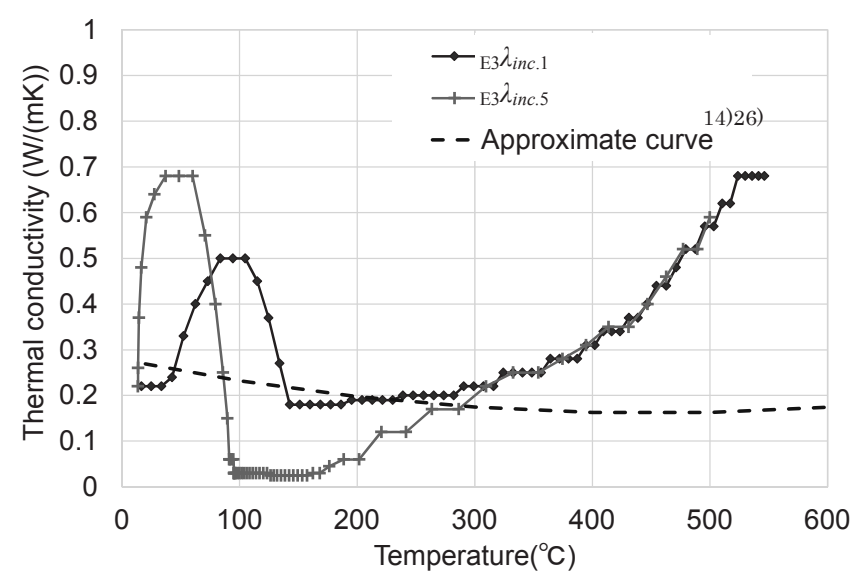

Fig. 14 Comparison of inclusive thermal conductivities and approximate curves of thermal conductivities 
ては、せっこうボードの熱伝導性に加えて自由水の熱伝導性及び顕 熱による影響が含まれていると考えられ、 $100^{\circ} \mathrm{C}$ 超においては蒸発 潜熱により包括熱伝導率が低下している。また、せっこうボードに は自由水よりも結晶水の方が多く含まれているため、結晶水が蒸発 する温度域とされる $150^{\circ} \mathrm{C}$ 付近（裏面温度では $120^{\circ} \mathrm{C}$ 付近）におい て包括熱伝導率が最も低くなっている。その後、せっこうボードに 生じたクラックによって熱が伝わりやすくなり、非加熱側の表面紙 の燃焼によって熱が発生し、非加熱側に近い包括熱伝導率が $200^{\circ} \mathrm{C}$ から急激に上昇している。加熱実験において、E1 では $350^{\circ} \mathrm{C}$ 付近、 E3 では $500^{\circ} \mathrm{C}$ 付近にて燃え抜けていることから、 $300^{\circ} \mathrm{C}$ 付近から $\lambda_{\text {inc. } 1} \sim \lambda_{\text {inc. } .5}$ の間の差がなくなる主要因はクラックであり、温度の上 昇に伴って材料内部の損傷度合の差が小さくなっているといえる。 また、高温になるにつれて包括熱伝導率が上昇している。なお、Fig. 11 及び Fig. 13 中の温度を示す横軸は Fig. 8 における $\theta^{\prime}$ とし、分割 された各要素の表裏面温度の平均值（式(8)）とした。

Fig. 14 に包括熱伝導率及び既往の熱伝導率の近似曲線 ${ }^{14)}$ 26) を示

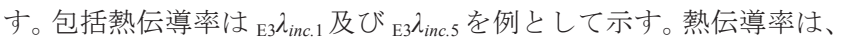
絶乾状態にて測定を行っており、400 $500^{\circ} \mathrm{C}$ の間で最も值が小さく なることが知られている。このとき、材料には水分が含まれておら ず蒸発潜熱による值の変化は見られないが、防耐火試験では $5 \%$ 以 下の含水率の材料を使用して行われるため、包括熱伝導率は水分の

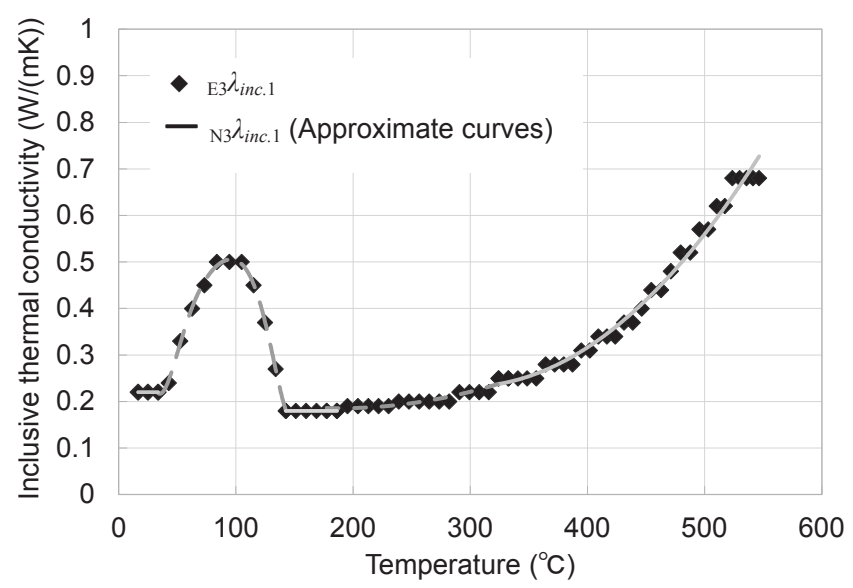

Fig. 15 Estimated inclusive thermal conductivity and approximate curves (heated side)

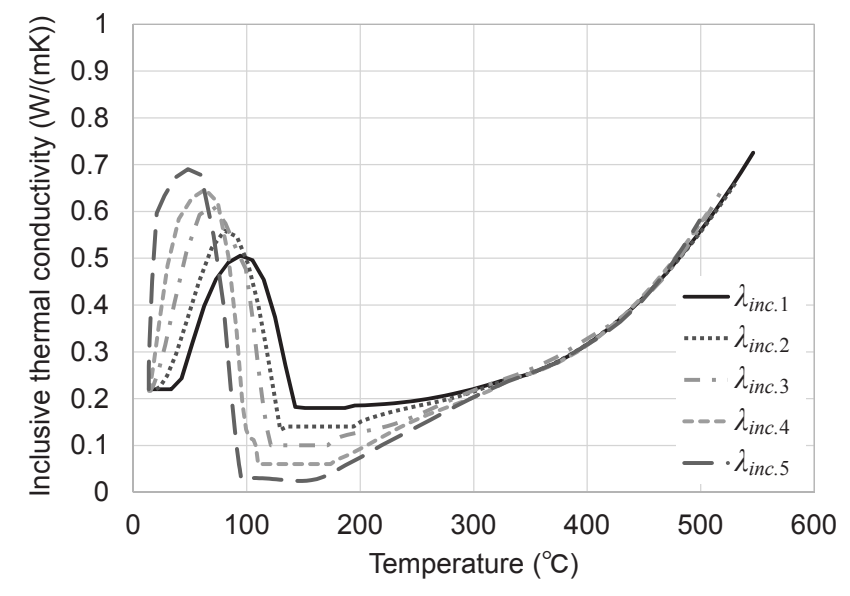

Fig. 16 Approximate curves of inclusive thermal conductivities (N3)
挙動を含み、温度上昇に伴って初期值からの值の変動が生じている。 $\lambda_{\text {inc. } 1}$ においても $100^{\circ} \mathrm{C}$ 以下の包括熱伝導率が上昇している要因は、 初期状態にて分割層内部に水分が存在しているためであり、 $\lambda_{\text {inc. } 1}$ よ りも $\lambda_{\text {inc. }}$ の方が低温で高い值となる主な原因は水分移動によると考 えられる。また、 $300^{\circ} \mathrm{C}$ 以降において、包括熱伝導率と既往の熱伝導 率が温度上昇に伴って乘離している。これは、片面加熱条件から推 定される包括熱伝導率がせっこうボードに生じるクラックの影響を 捉えているのに対して、均一な加熱条件で測定される熱伝導率は、 その影響を十分には捉えきれてないためと考えられる。

防耐火試験においては、裏面温度は耐火繊維パッドを使用して測 定する ${ }^{1)}$ た、推定される包括熱伝導率は耐火繊維パッドの影響を 包含している。本研究で目的とする裏面温度の予測も、同様の試験 における結果であるため、耐火繊維パッドの影響をも包含する包括 熱伝導率を使用寸ることで予測精度が確保できるといえる。

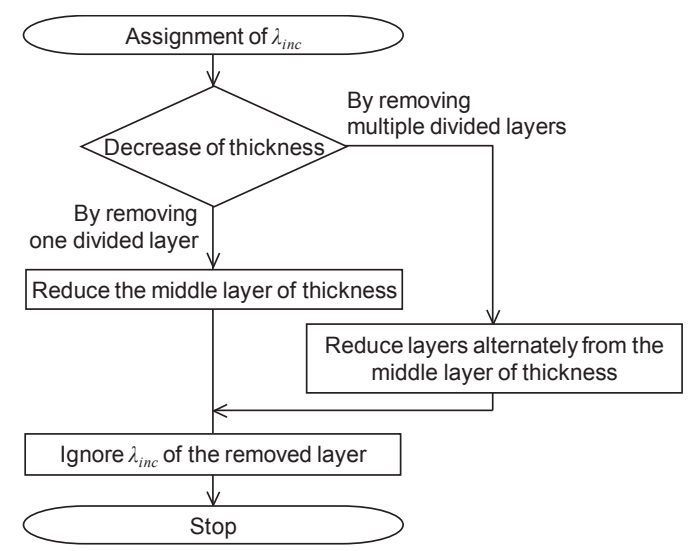

Fig. 17 Subroutine for assignment of inclusive thermal conductivities shown as a flow chart

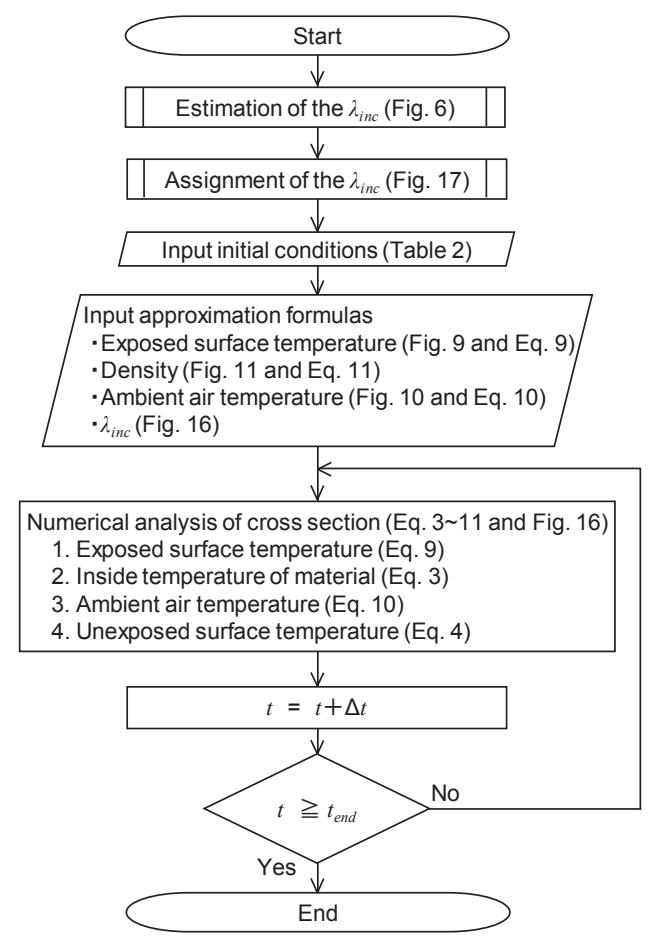

Fig. 18 Main routine calculation of unexposed surface temperature shown as a flow chart 


\section{4. 包括熱伝導率を用いた遮熱性予測の妥当性の検証}

\section{1. 検証手順}

Fig. 13 に示す E3 の包括熱伝導率は特定の温度でピーク・ディッ プを持つため、数值計算に用いることができるよう温度域ごとに区 間分けを行い、6 次以下の多項式近似とした。例として、Fig. 15 に

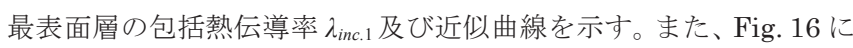
N3の包括熱伝導率（E3の包括熱伝導率を近似式化したもの）を示 す（各包括熱伝導率の近似式については、補遺を参照）。

本研究では、この ${ }_{\mathrm{N} 3} \lambda_{\text {inc }}$ を基に、厚さの異なるせっこうボード $\mathrm{N} 1$ （厚さ $9 \mathrm{~mm}$ ）及び $\mathrm{N} 2$ （厚さ $12 \mathrm{~mm}$ ）における各分割要素の包括熱 伝導率 ${ }_{\mathrm{N} 1} \lambda_{\text {inc }}$ 及び ${ }_{\mathrm{N} 2} \lambda_{\text {inc }}$ を設定し、それらの值を用いて $\mathrm{N} 1$ 及び $\mathrm{N} 2$ の 裏面温度を予測し、実験結果と比較した。

包括熱伝導率の割り当てのフローチャートをFig. 17 に示す。Fig. 17 は、材厚を薄くする場合を想定したものであり、「By removing one divided layer」は分割層を 1 層削減する場合、「By removing multiple divided layers」は複数の分割層を削減する場合をそれぞ れ示す。また、裏面温度予測のフローチャートを Fig. 18 に示す。

\section{2. 包括熱伝導率の設定}

差分法を用いて熱伝導計算を行う場合、材料を一定の厚さで要素 分割する。そのため、材質が同じで厚さの異なる材料について裏面 温度予測を行う場合は、熱伝導計算に必要となる分割層の数も異な る。したがって、厚さの変更に対応するには、材料厚さの差と等し くなるだけの分割層の数を基準となる材料の分割層の数から削減す る（Fig. 19 参照）。また、包括熱伝導率は分割層ごとに特定の值を
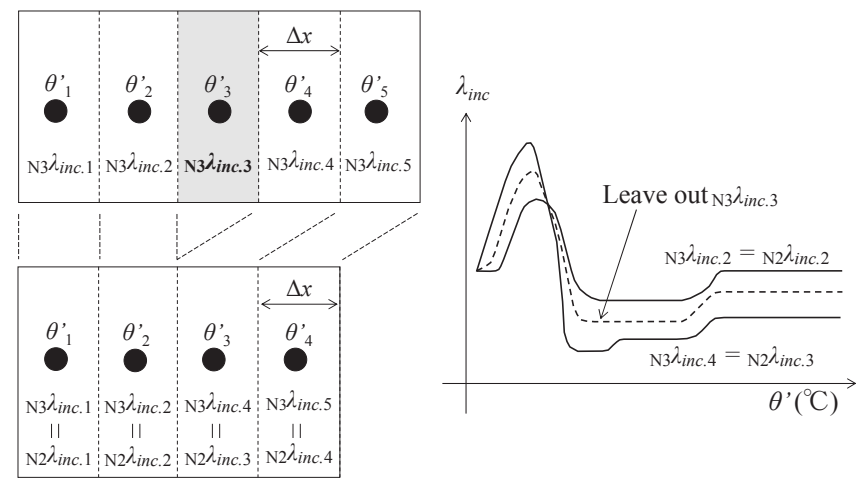

(a) Numerical analysis of $\mathrm{N} 2$

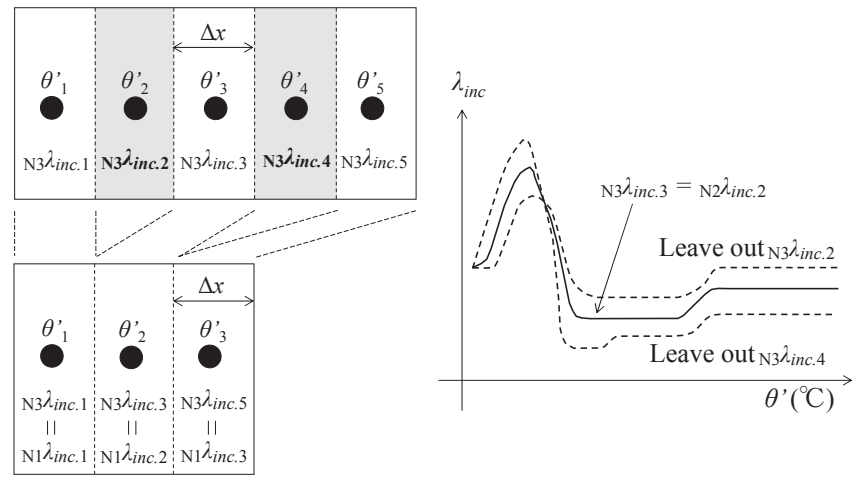

(b) Numerical analysis of $\mathrm{N} 1$

Fig. 19 How to decrease the number of inclusive thermal conductivities
持つが、最表面層と最裏面層の包括熱伝導率は、外部からの熱伝達 やクラックの影響を多く受け、厚さに係わらずほぼ一定と考えられ るため、厚さを変化させて予測計算を行う場合は、表裏面層よりも 内側の分割層を減少させる。

Fig. 7 に示寸厚さ $12 \mathrm{~mm}$ の $\mathrm{N} 2$ について予測計算を行う場合、基 準となる厚さ $15 \mathrm{~mm} の \mathrm{~N} 3$ から分割層（厚さ $3 \mathrm{~mm}$ ）を 1 つ削減 し、残された分割層の包括熱伝導率はそのままの值を用いることと する。具体的には、Fig. 19(a) における加熱側から 3 層目を削減す るため、N3 の包括熱伝導率のうち $\lambda_{\text {inc.3 }}$ が不要となる。

次に、厚さ $9 \mathrm{~mm} の \mathrm{~N} 1$ について予測計算を行う場合、基準とな る厚さ $15 \mathrm{~mm}$ の $\mathrm{N} 3$ から、分割層（厚さ $3 \mathrm{~mm}$ ）を 2 つ削減する。 このとき、材料内部の温度分布、及び、包括熱伝導率分布は本来な めらかであることを考慮し、削減する分割層の箇所を 1 つおきとす る。具体的には、Fig. 19(b) における加熱側から 2 層目及び 4 層目

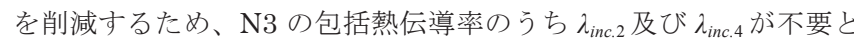
なる。

\section{3. 遮熱性予測の妥当性の検討}

4.2 節で推定した N1〜N3 の包括熱伝導率、及び、Table 2 に示寸 初期条件を基に、せっこうボードの裏面温度 N1〜N3 を算出した。 このとき、式(2)に示す一次元非定常熱伝導方程式を用い、近似式化 した包括熱伝導率を式 (7) として式(4) 及び式(5)に代入し計算を行 った。

まず、N1〜N3 の包括熱伝導率の妥当性を検討するため、表面温 度は E1〜E3 それぞれの実験結果の近似式とした。実験結果と計算 結果の比較を Fig. 20 に示す。包括熱伝導率の基となった $15 \mathrm{~mm}$ (N3) と分割層 1 つ分の厚さ違いとなる $12 \mathrm{~mm}$ の計算結果 N2 では、 実験結果との差が非常に少なく良好な予測ができており、防耐火試 験における遮熱性の判定基準である平均裏面温度上昇值 $140 \mathrm{~K}$ を超 過する時間に差がみられない。一方で、分割層の削減数が 2 つとな る $9 \mathrm{~mm}$ の $\mathrm{N} 1$ では温度上昇勾配は良好であるが、急激な上昇とな る時間のずれが $\mathrm{N} 2$ と比較して大きく、 $140 \mathrm{~K}$ 超過時間に 1.5 分の 差が生じている。その理由として、N1の方が N2 よりも材料の厚さ が薄く、削減する分割層が多くなり、材料内部に存在する包括熱伝 導率の連続性が低下し、温度予測精度が低下したためと考えられる。

次に、 $\mathrm{N} 1$ 及び $\mathrm{N} 2$ の裏面温度予測の妥当性を検討するため、 E3 の表面温度の近似式を N1〜N3 の表面温度とした場合の実験結果 と計算結果の比較を Fig. 21 に示寸。 $100^{\circ} \mathrm{C}$ 未満における停滞温度は よく一致しているが、結晶水が蒸発する $120^{\circ} \mathrm{C}$ 停滞温度は実験結 果とずれが生じている。また、水分がなくなった後の立ち上がり時 間においても実験結果とのずれが生じており、140K 超過時間の差 が N2 では 2 分、N1 では 3 分であった。基準となる N3 から削減す る分割層の数が増えるほどその差は大きくなっており、これは Fig. 20 と同様である。

本研究では、炉内と試験体表面における熱伝達の検討における煩 雑さを回避するために、表面温度を試験体の内部 $1 \mathrm{~mm}$ の位置の温 度としている。したがって、表面温度の測定精度が重要となるため、 より高い精度の温度予測結果を求める際には材料の厚さの違いによ って生じる表面温度の変化を検討する必要がある。また、包括熱伝 導率を削減する際には、その連続性を確保するなどの検討を要する。 


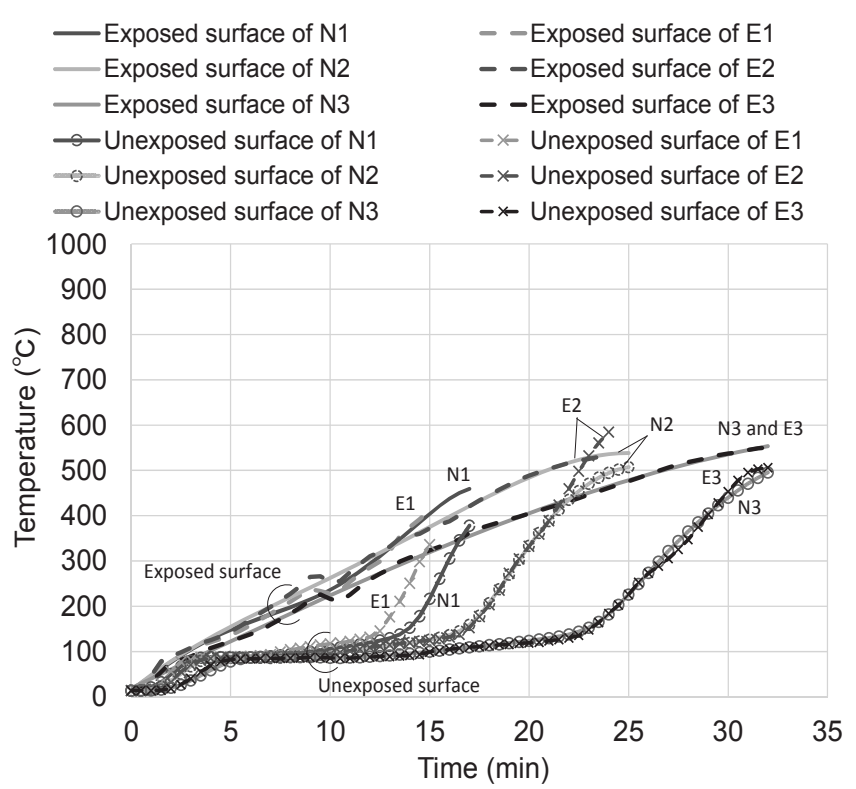

Fig. 20 Comparison of fire-resistance test results and numerical results (using the exposed surface tempearture of each material)

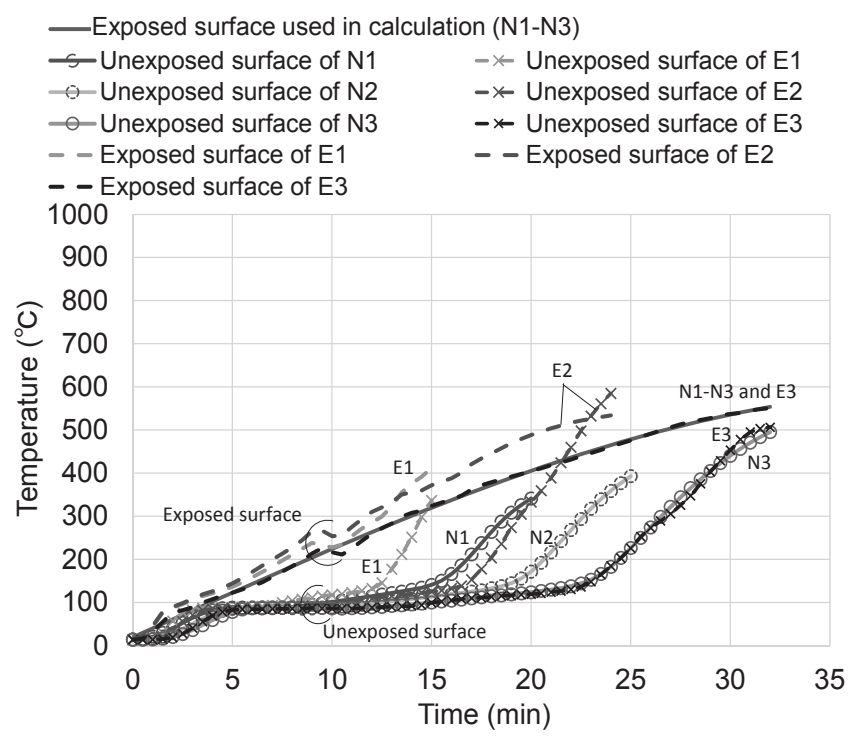

Fig. 21 Comparison of fire-resistance test results and numerical results (unify the exposed surface temperature to E3)

しかしながら、裏面温度上昇值 $140 \mathrm{~K}$ を超過する時間を基準として 実験結果と計算結果の差を検討したところ、本研究で推定した N3 の包括熱伝導率を用いることで、せっこうボードの厚さを薄くした 場合の裏面温度の予測が精度よくできるといえる。

\section{5. まとめ}

本研究では、実務的な防耐火試験時の遮熱性予測を目的として包 括熱伝導率を提案した。また、防耐火試験における温度測定結果、 及び、一次元熱伝導数值解析モデルを用いて包括熱伝導率を推定し、 せっこうボードの厚さを薄くした場合の裏面温度の予測を行った。

せっこうボードの包括熱伝導率は、高温になるにつれて上昇する 推定結果となった。 $300^{\circ} \mathrm{C}$ 付近から $\lambda_{\text {inc. } 1} \sim \lambda_{\text {inc. } 5}$ の間の差がなくなり、 材料内部において同一温度の時にはいずれも同じ值となった。
裏面温度の予測では、せっこうボードの厚さを $15 \mathrm{~mm}$ から 12 $\mathrm{mm}$ 及び $9 \mathrm{~mm}$ に薄くした場合、分割層の削減数が少ない $12 \mathrm{~mm}$ のほうが精度の高い結果を得られることが分かった。

以上より、本研究で提案した包括熱伝導率を用いることで、せっ こうボードを薄くした場合の遮熱性を予測することができるといえ る。

本研究で提案した包括熱伝導率は、比熱・密度・熱伝導率の温度 依存性を全て包含できると考えられる。しかし、今回の検討で取り 扱ったせっこうボードは水分の影響を大きく受ける材料であり、水 分の影響に特化した包括熱伝導率を用いた際の遮熱性の予測精度に ついての検討を行ったため、密度を一定としなかった。比熱及び密 度を一定とした場合の包括熱伝導率の予測及びそれらを用いた際の 遮熱性の予測精度については、今後の検討としたい。

また、昨今の住宅では複層構成の外壁が一般的となっているため、 今後は、複層壁において包括熱伝導率の推定及び裏面温度予測の適 用可能性について詳しく検討する。また、本研究で推定した包括熱 伝導率と複層壁で推定する包括熱伝導率との整合性についてもあわ せて検討する。

\section{参考文献}

1 ) Ex, GBRC: The method book of fire-proof performance test and evaluation, 2015. [in Japanese] 例えば、(一財) 日本建築総合試験所：防耐火性能試験・評価業務方法書, 2015.

2 ) Ishihara, S.: $<$ REVIEW $>$ Smoke and Toxic Gases Produced during Fire, Wood research and technical notes, Kyoto University, 16, pp. 49-62, 1981. [in Japanese] 石原茂久: <総説>火災時の煙と有毒ガス, 木材研究・資料 16 , 京都大学木材 研究所, 1981.

3 ) ISO 834-1: Fire-resistance tests - Elements of building construction Part 1: General requirements, 1999.

4 ) Building Guidance Division, Housing Bureau, the Ministry of Land, Infrastructure and Transport, Building Research Institute, Japan Conference of Building Officials and The Building Center of Japan, eds.:Taikaseinoukenshoho no kaisetsu oyobi keisanrei to sono kaisetsu, Inoueshoin, 2001. [in Japanese]

国土交通省住宅局建築指導課, 国土交通省建築研究所, 日本建築主事会 議, (財) 日本建築センター編: 耐火性能検証法の解説及び計算例とその解 説, 井上書院, 2001.

5 ) Matsumoto, M.: Study on the simultaneous movement and moisture accumulation of heat and moisture in the building wall, Doctoral Thesis, Kyoto University, 1979. [in Japanese]

松本衛: 建築壁体における熱・水分の同時移動および水分蓄積に関する研 究, 京都大学博士論文, 1979.

6 ) Yoshida, M.: Study on the Fire Damage diagnosis method of concretebased structural member, Doctoral Thesis, Osaka University, 1997. [in Japanese]

吉田正友: コンクリート系構造部材の火害診断手法に関する研究, 大阪大 学博士論文, 1997 .

7 ) Obata, H., Nakamura, H. and Tanibe, T.: Heat conduction analysis of concrete coated with a wet refractory coating material, Proceedings of the Japan Concrete Institute 25(1), pp. 1853-1858, 2003. [in Japanese] 小幡浩之, 中村秀三, 谷辺徹 : 湿式耐火被覆材を被覆したコンクリートの 熱伝導解析, コンクリート工学年次論文集, Vol.25, No.1, pp. 1853-1858, 2003.

8 ) Yoshida, S., Kawarasaki, M., Kawahara A. and Hiradate, R.:

Development of estimation method for fire resistance of wood-stud wall -Estimation method for residual shape and strength of wood-column following wood pyrolysis-, Journal of the Hokkaido Forest Products Research Institute 539, pp.16-32, 2010. [in Japanese] 
由田茂一, 河原㠃政行，河原映，平舘亮一：木造軸組外壁を対象とした耐 火性能推定手法の開発一軸組部材の熱分解による断面形状と強度の推定 一，林産試験場報,第 539 号, pp.16-32, 2010.

9 ) Eurocode 4: Design of Composite Steel and Concrete Structures, Part 1.2: Structural Fire Design, EN 1994-1-2, 2005.

10) Imagawa, Y., Takehara, K., Nagira, H., Ohyama, O. and Kurita, A.: Analytical Study on Evaluation of Fire Resistance for Steel-Concrete Composite Bridges, Journal of Structural Engineering A. Japan Society of Civil Engineers, Vol. 53A, pp.1107-1116, 2007. [in Japanese] 今川雄亮, 竹原和夫, 柳楽英俊, 大山理, 栗田章光 : 鋼・コンクリート単純 合成桁橋の耐火性能評価に関寸る解析的研究, 土木学会構造工学論文集 A, 第 53 回, pp.1107-1116, 2007.

11) Park, S., Kim, H., Kim, H. and Hong, K. : Fire Resistance of the Korean Asymmetric Slim Floor Beam Depending on Load Ratio, Journal of Asian Architecture and Building Engineering, Vol. 10, No. 2, pp. 413420, 2011.11.

12) Saito, H. and Morita, T.: Calculating Temperatures in Concrete Elements Exposed to Fire, Technical research report of Shimizu Corporation, No. 80, pp. 25-32, 2004. [in Japanese]

齋藤秀人, 森田武 : 火災時におけるコンクリート内部温度の予測手法, 清 水建設研究報集, 第 80 号, pp.25-32, 2004 .

13) Mizukami, T.: Temperature rise simple prediction method of humidified partition wall that is exposed to the compartment fire, Doctoral Thesis, Kyoto University, 2012. [in Japanese]

水上点晴 : 区画火災に曝される含湿区画壁の温度上昇簡易予測手法, 京都 大学博士論文, 2012 .

14) Hirayama, T., Fujita, K., Suzuki, J., Ohmiya, Y. and Yamamoto, H.: Temperature-increase characteristics of gypsum-board assemblies exposed to several fire curves : Part2 Temperature prediction model based on one-dimensional unsteady heat conduction analysis, Summaries of Technical Papers of Annual Meeting, Architectural Institute of Japan, Fire Safety, pp. 377-378, 2014. [in Japanese] 平山貴至, 藤田航平, 鈴木淳一, 大宮喜文, 山本弘樹: 多様な加熱を被るせ っこうボード乾式間仕切り壁の温度上昇特性〜その 2 非定常一次元熱伝 導解析による温度予測モデル〜, 日本建築学会大会学術講演梗概集, 防火, pp. 377-378, 2014.

15) Ishihara, T., Yoshinaka, H., Harada, K., Yusa, S. and Wakamatsu, T.: Parameter Estimation Method to Extrapolate the Temperature Measurement in Fire Resistance Test, AIJ Kanto Branch Research report collection, No. 68, pp. 173-176, 1998. [in Japanese] 石原慶大, 吉中宏, 原田和典, 遊佐秀逸, 若松孝旺: 柱の耐火試験結果のパ ラメータ推定法による読み替え, 日本建築学会関東支部研究報告集(68), pp. 173-176, 1998.

16) Harada, K. and Terai, T.: A Study on Heat and Moisture Transfer in Fire Resistance Test -Sensivity Analysis of Various Factors Affecting the Result-, AIJ Kinki Branch research report Collection, Architecture and Planning, No. 28, pp. 173-176, 1988. [in Japanese]

原田和典, 寺井俊夫 : 而火試験時のコンクリート床版内の熱、水分移動に 関する研究(耐火試験結果に影響を及ぼす要因の感度解析), 日本建築学会 近畿支部研究報告集, 計画系(28), pp. 173-176, 1988.

17) Harada, T., Awano, M., Shiire, T., Furumura F. and Tanaka, T.: Change of temperature conductivity and thermal conductivity of building materials in high temperature -Measuring apparatus and method-, Summaries of technical papers of annual meeting Architectural Institute of Japan, No. 36(2), pp. 97-100, 1965. [in Japanese] 原田有, 粟野満, 仕入豊和, 古村福次郎, 田中敏郎: 高温度における建築材 料の温度伝導率及び熱伝導率の変化(測定装置及び方法), 日本建築学会研 究発表会梗概集，巻号 36(2), pp. 97-100, 1965.

18) Ouchi, T., Fujinaka, H. and Nakamura, K.: Thermal conductivity of fire-proofing materails at high temperatures (Part 1. Measuring method and outline of measuring results), Summaries of technical papers of Annual Meeting Architectural Institute of Japan, A, pp. 611612, 1985. [in Japanese]

大内富夫, 藤中英生, 中村賢一 : 而火被覆材の高温時の熱伝導率(その 1 .測 定方法と测定結果の概要), 日本建築学会大会学術講演梗概集, A, pp.611612,1985
19) Fujinaka, H., Ouchi, T. and Nakamura, K.: Thermal conductivity of fire-proofing materails at high temperatures (Part 2. Commet for test results), Summaries of technical papers of Annual Meeting Architectural Institute of Japan, A, pp. 613-614, 1985. [in Japanese] 藤中英生, 大内富夫, 中村賢一: 耐火被覆材の高温時の熱伝導率(その 2. 測 定結果と考察), 日本建築学会大会学術講演梗概集, A, pp.613-614, 1985.

20) Nagao, K. and Nakane, S.: Thermal Conductivity of the Concrete Subjected to High Temperature, Proceedings of the Japan Concrete Institute 12(1), pp. 395-400, 1990. [in Japanese]

長尾覚博, 中根淳 : 高温加熱されるコンクリートの熱伝導率, コンクリー 卜工学年次論文集, vol.12, No.1, pp.395-400, 1990.

21) Japan Society of Thermophysical Propeties, ed.: Thermophysical Propeties Handbook, Tokyo, Yokendo Co., Ltd., 1990. [in Japanese] 日本熱物性学会編：熱物性ハンドブック, 養賢堂, 1990.

22) JIS A 6901: gypsum boards, 2014.

JIS A 6901 : せっこうボード製品, 2014.

23) JIS R 1611: Measurement methods of thermal diffusivity, specific heat capacity, and thermal conductivity for fine ceramics by flash method, 2010.

JIS R 1611 : ファインセラミックスのフラッシュ法による熱拡散率・比熱 容量・熱伝導率の測定方法, 2010 .

24) JIS R 2251-1:Test methods for thermal conductivity of refractory materials - Part 1: Hot-wire method (cross-array), 2007. JIS R 2251-1 : 耐火物の熱伝導率の試験方法一第 1 部 : 熱線法(直交法), 2007

25) Tanaka, T.: Kenchiku Kasai Anzen Kougaku Nyumon, The Building Center of Japan, 2002. [in Japanese] 田中哮義 : 建築火災安全工学入門, (財) 日本建築センター, 2002.

26) AIJ: Guide Book for Fire-Resistive Performance of Structural Materials, Maruzen, 2009. [in Japanese] 日本建築学会 : 構造材料の耐火性ガイドブック, 丸善, 2009 .

補遺

Fig. 16 の近似式を、式 $(\mathrm{a}-1) \sim(\mathrm{a}-26)$ に示す。 $\lambda_{i n c .1}$ は式 $(\mathrm{a}-1) \sim(\mathrm{a}-5) 、 \lambda_{\text {inc. } 2}$ は式(a-6)〜 (a-9)、 $\lambda_{\text {inc.3 }}$ は式 $(\mathrm{a}-10) \sim(\mathrm{a}-14) 、 \lambda_{\text {inc. } 4}$ は式 $(\mathrm{a}-15) \sim(\mathrm{a}-19) 、 \lambda_{\text {inc.5 }}$ は 式 $(a-20) \sim(a-26)$ である。

$$
\begin{aligned}
{ }_{N 3} \lambda_{\text {inc.1 }}^{\mathrm{n}+1}= & 0.22 \\
{ }_{N 3} \lambda_{\text {inc. } 1}^{\mathrm{n}+1}= & 1.07144430473667 \times 10^{-11} \theta_{1}^{\prime \mathrm{n}^{6}} \\
& -5.73251324534603 \times 10^{-9} \theta_{1}^{\prime \mathrm{n}^{5}} \\
& +1.24095454855748 \times 10^{-6} \theta^{\prime \mathrm{n}^{4}} \\
& -1.39343198179509 \times 10^{-4} \theta_{1}^{\prime \mathrm{n}^{3}} \\
& +8.46894067290338 \times 10^{-3} \theta^{\prime \mathrm{n}^{2}} \\
& -0.254814519190188 \times \theta^{\prime \mathrm{n}}{ }_{1} \\
& +3.15464106009703
\end{aligned}
$$$$
\left(\theta^{\prime \prime}{ }_{1}^{\mathrm{n}} \leq 33.55\right) \quad(\mathrm{a}-1)
$$$$
\left(33.5 \leq \theta_{1}^{\prime n} \leq 142.69\right)
$$

${ }_{N 3} \lambda_{\text {inc. } 1}^{\mathrm{n}+1}=0.18$

$\left(142.69<\theta^{\prime \mathrm{n}} \leq 186.41\right) \quad(\mathrm{a}-3)$

$\begin{aligned}{ }_{N 3} \lambda_{\text {inc. } 1}^{\mathrm{n}+1}= & 2.24671732989185 \times 10^{-6} \theta_{1}^{\mathrm{n}^{2}} \\ & -7.52467594737434 \times 10^{-4} \theta_{1}^{\prime{ }^{\mathrm{n}}} \\ & +0.24432673012747\end{aligned}$

${ }_{N 3} \lambda_{\text {inc. } 1}^{\mathrm{n}+1}=7.97590967408131 \times 10^{-6}{\theta^{\prime}}_{1}^{\mathrm{n}^{2}}$ $-4.74549173348831 \times 10^{-3} \theta_{1}^{\prime n}$ $+0.937915274087322$

${ }_{\mathrm{N}} \lambda_{\text {inc. } 2}^{\mathrm{n}+1}=1.36022656658503 \times 10^{-10}{\theta^{\prime}}_{2}^{\mathrm{n}^{5}}$ $-3.32500307757268 \times 10^{-8} \theta_{2}^{\prime^{4}}$ $+5.62411235919975 \times 10^{-7} \theta_{2}^{\prime \mathrm{n}^{3}}$ $+2.44730517150718 \times 10^{-4} \theta_{2}^{\prime \mathrm{n}^{2}}$ $-8.35171311698851 \times 10^{-3} \theta_{2}^{\prime \mathrm{n}}$ $+0.28806936385701$

$\left(324.24<\theta^{\prime}{ }_{1}^{\mathrm{n}}\right)$

$\left(\theta_{2}^{\prime \mathrm{n}} \leq 129.65\right)$

${ }_{N 3} \lambda_{\text {inc. } 2}^{\mathrm{n}+1}=0.14$

$\left(129.65<\theta^{\prime \mathrm{n}} \leq 194.22\right)$ 


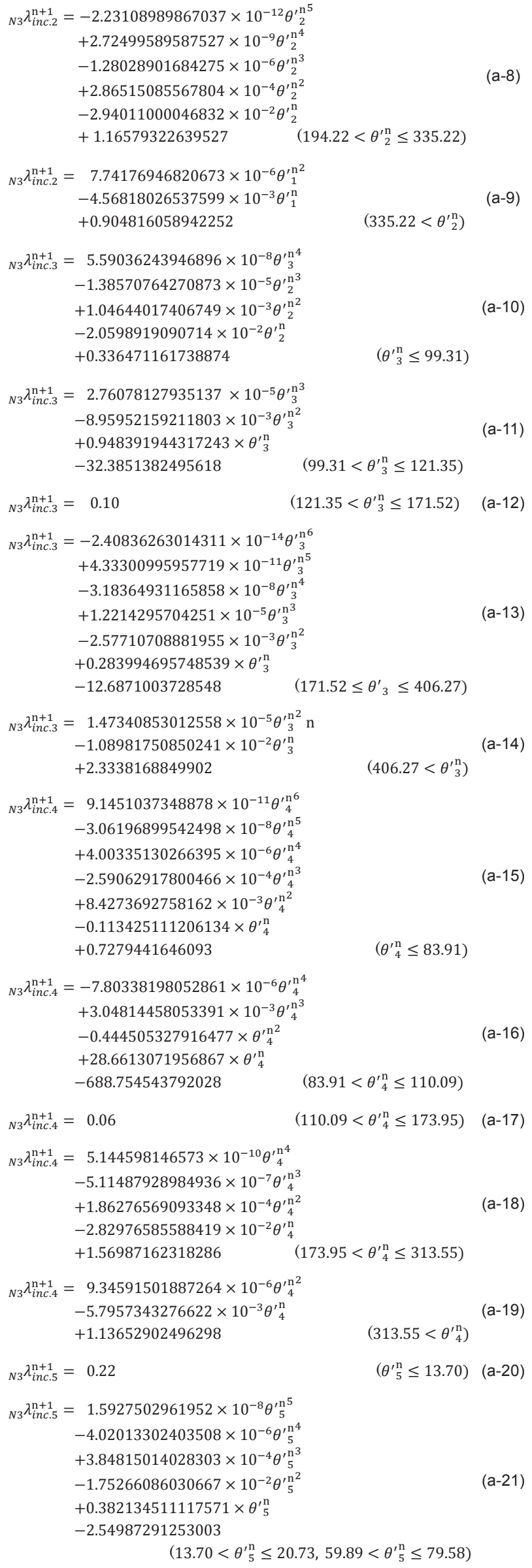

$$
\begin{aligned}
{ }_{N 3} \lambda_{\text {inc. } 5}^{\mathrm{n}+1}= & -1.12639868348299 \times 10^{-4} \theta_{{ }_{5}}^{\mathrm{n}^{2}} \\
& +1.11893542050516 \times 10^{-2} \theta_{5}^{\prime \mathrm{n}} \\
& +0.411880873436493
\end{aligned}
$$

$$
\begin{aligned}
{ }_{N 3} \lambda_{\text {inc. } 5}^{\mathrm{n}+1}= & 5.2102406512714 \times 10^{-4} \theta_{{ }_{5}^{\prime}}{ }^{2} \\
& -0.115160363777775 \times \theta^{\prime}{ }_{5}^{\mathrm{n}} \\
& +6.2685572223735
\end{aligned}
$$

${ }_{N 3} \lambda_{\text {inc. } 5}^{\mathrm{n}+1}=7.45387912194026 \times 10^{-13} \theta_{5}^{\prime{ }^{\mathrm{n}} 6}$

$-6.96627747670309 \times 10^{-10} \theta^{\prime n^{5}}$ $+2.66643186317009 \times 10^{-7} \theta_{5}^{\prime \mathrm{n}^{4}}$ $-5.33352682821752 \times 10^{-5} \theta_{5}^{\mathrm{n}^{3}}$ $+5.87379571044542 \times 10^{-3}{\theta^{\prime \prime}}_{5}^{2}$ $-0.337846191915513 \times \theta^{\prime n}$ $+7.96867412742796$

${ }_{N 3} \lambda_{\text {inc. } 5}^{\mathrm{n}+1}=2.3396967830149 \times 10^{-12}{\theta^{\prime}{ }_{5}{ }^{\mathrm{n}}}$ $-3.2332268858654 \times 10^{-9} \theta_{5}^{\prime n^{4}}$ $+1.75347941039566 \times 10^{-6} \theta_{5}^{\prime \mathrm{n}^{3}}$ $-4.67345018153729 \times 10^{-4} \theta_{5}^{\prime \mathrm{n}^{2}}$ $+6.258712387678 \times 10^{-2} \theta^{\prime n}$ $-3.35177307820827$

${ }_{N 3} \lambda_{\text {inc. } 5}^{\mathrm{n}+1}=1.41642299709274 \times 10^{-5} \theta_{5}^{\prime \mathrm{n}^{2}}$ $-1.00489994011707 \times 10^{-2} \theta_{5}^{\prime \mathrm{n}}$ $+2.06734552264518$ $\left(392.70<\theta^{\prime}{ }_{5}^{\mathrm{n}}\right)$ 


\title{
STUDY ON PREDICTION METHOD FOR INSULATION OF GYPSUM BOARD \\ USING “INCLUSIVE THERMAL CONDUCTIVITY” IN FIRE-RESISTANCE TEST
}

\author{
Kimie YOSHITANI*, Takafumi SHIMIZU** and Masatomo YOSHIDA*** \\ * Daiwa House Industry Central Research Laboratory \\ ** Daiwa House Industry Central Research Laboratory, Dr.Eng. \\ *** Prof., Osaka Institute of Technology, Dr.Eng.
}

In this study, a prediction method of the unexposed surface temperature of a wall is proposed using "inclusive thermal conductivity" that takes into consideration heat and mass transfer in a material containing moisture. Inclusive thermal conductivity is estimated based on the results of temperature measurements from actual fire tests. The proposed method will enable the estimation of thermal conductivities of materials that are difficult to assess using conventional technologies. The inclusive thermal conductivities are estimated by using the finite differential method.

The estimated thermal conductivities of gypsum board were based on the results of temperature measurements from actual fire test which was conformed in ISO834. On the estimation of the inclusive thermal conductivity, the calculated internal temperatures of the materials and exposed surface temperature on the non-heated side were compared with the experimental results. The inclusive thermal conductivities were estimated considering the moisture behavior and cracks in the materials.

The inclusive thermal conductivities have some peaks and troughs at various temperatures. The inclusive thermal conductivity of gypsum board becomes larger as the temperature becomes higher. Furthermore, an approximate formalization of the inclusive thermal conductivities was conducted in order to use them in numerical calculations, they are segmented for each temperature region.

In order to verify the usefulness of inclusive thermal conductivities for temperature prediction, the unexposed surface temperatures were predicted for decreasing material thicknesses of gypsum board. For changing specimen thickness, the inclusive thermal conductivities of predictive calculations were performed by removing layers of the same thickness as the divided layer.

Calculations using this inclusive thermal conductivity sufficiently captured the temperature history. Unexposed surface temperature prediction is affected by the exposed surface temperature of the fire-resistance test, and that is a high accuracy as the difference of the material thickness is smaller. Exposed surface temperature obtained from the fire-resistance test result influenced the prediction of the unexposed surface temperature. The results confirmed that the inclusive thermal conductivity reflects the influence of moisture movement, evaporation of water, deterioration, or crack formation in the material at high temperatures.

The prediction accuracy of numerical analysis using the inclusive thermal conductivity was conformed to be practically sufficient. 